\title{
PHOSPHORUS RUNOFF FROM SOILS RECEIVING LIQUID DAIRY AND SWINE MANURES AMENDED WITH MINE DRAINAGE RESIDUAL
}

\author{
C. D. Church, R. S. Hedin, R. B. Bryant, A. G. Wolfe, \\ J. T. Spargo, K. R. Elkin, L. Saporito, P. J. A. Kleinman
}

\begin{abstract}
HighLIGHTS
- Concern over nutrient runoff from agriculture has prompted research to limit phosphorus (P) mobility.

- Mine drainage residuals (MDRs) can reduce phosphorus solubility in soils, sediments and liquid manure slurries.

- MDR amendment resulted in lower dissolved phosphorus in runoff from sites treated with dairy manure slurry, but not with swine manure slurry.

- This study underscores the value of testing under field conditions before making recommendations.
\end{abstract}

\begin{abstract}
Concern over nutrient runoff from agriculture has prompted considerable research on amendments to limit phosphorus $(P)$ solubility of manure slurries and P mobility following land application of the slurry. The concept of solving one industry's problem with another industry's problem is attractive, but successful examples are uncommon. Mine drainage residual (MDR), generated from the process of neutralizing acid discharge from coal mines, has been shown to reduce soluble P in soils, sediments and manure slurries. We therefore sought to test whether amending manure slurries with MDR was effective at reducing $P$ in runoff once that slurry was applied to agricultural soils. A series of simulated rainfall experiments revealed that amending dairy manure slurry with MDR resulted in significantly less flow weighted dissolved $P$ concentrations and loads in runoff. However, the same effect was not observed with runoff from soils amended with swine manure slurry, despite a greater reduction of water extractable $P$ in swine manure slurry with MDR addition than in dairy manure slurry. This study underscores the value of testing amendments under field conditions before making manure management recommendations. NonCommercial-NoDerivatives 4.0 International License https://creative commons.org/licenses/by-nc-nd/4.0/
\end{abstract}

Submitted for review on 30 September 2019 as manuscript number NRES 13715; approved for publication as a Research Article by the Natural Resources \& Environmental Systems Community of ASABE on 18 January 2021.

Mention of trade names or commercial products in this publication is solely for the purpose of providing specific information and does not imply recommendation or endorsement by the U.S. Department of Agriculture (USDA). USDA is an equal opportunity provider and employer. The U.S. Department of Agriculture prohibits discrimination in all its programs and activities on the basis of race, color, national origin, age, disability, and where applicable, sex, marital status, familial status, parental status, religion, sexual orientation, genetic information, political beliefs, reprisal, or because all or part of an individual's income is derived from any public assistance program. (Not all prohibited bases apply to all programs.) Persons with disabilities who require alternative means for communication of program information (Braille, large print, audiotape, etc.) should contact USDA's TARGET Center at (202) 720-2600 (voice and TDD). To file a complaint of discrimination, write to USDA, Director, Office of Civil Rights, 1400 Independence Avenue, S.W., Washington, D.C. 20250-9410, or call (800) 795-3272 (voice) or (202) 720-6382 (TDD).

The authors are Clinton D. Church, Environmental Chemist, USDAARS, University Park, Pennsylvania; Robert S. Hedin, President, Hedin Environmental, Pittsburgh, Pennsylvania; Ray B. Bryant, Soil Scientist, USDA-ARS, University Park, Pennsylvania; Amy G. Wolfe, Director, NE Habitat Program, Trout Unlimited, Lock Haven, Pennsylvania; John T. Spargo, Director, Ag Analytical Services Lab, Pennsylvania State University, University Park, Pennsylvania; and Kyle R. Elkin, Analytical Chemist, Lou Saporito, Support Scientist, and Peter J. A. Kleinman, Soil Scientist, USDA-ARS, University Park, Pennsylvania. Corresponding author: Clinton Church, 3702 Curtin Road, University Park, PA 16802; phone: (814) 863-8760; email: Clinton.Church@ars.usda.gov.

Keywords. Manure, Phosphorus, Mine drainage residual, Engineered treatment, Simulated rainfall.

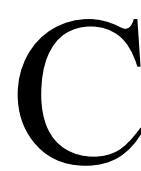

oncentrations of water-soluble forms of phosphorus $(\mathrm{P})$ in manure can dominate runoff once $\mathrm{P}$ in those manures are land applied (Sharpley and Moyer, 2000; Kleinman et al., 2002, 2004). As a result, there has been considerable emphasis on strategies that manipulate land application of manure to reduce P availability to runoff (Maguire et al., 2011; King et al., 2018). One approach to controlling dissolved P (DP) losses in runoff from soils receiving manure is to add materials that bind with $\mathrm{P}$, either directly to manures, or to soils, rendering it relatively insoluble (e.g. Moore et al., 1994, 2000; Smith et al., 2001; Dou et al., 2003; Kalbasi and Karthikeyan, 2004; Wilson et al., 2008; Brennan et al., 2011, 2014; Miller et al., 2011; Chardon et al., 2012; Allred, 2017; Kennedy et al., 2017).

Ideally, an amendment used to mitigate DP losses would: 1) rapidly convert DP into a relatively insoluble form; 2) promote reactions that remain stable under a range of environmental conditions; but (3) ensure $\mathrm{P}$ availability to 
growing crops. The major mechanisms of DP removal by amendments are: 1) adsorption, where DP is adsorbed to the surface of the substrate and is a highly reversible mechanism, 2) absorption, where DP is incorporated into the structure of the matrix and is a less reversible mechanism, and 3) precipitation of an insoluble phosphate salt, a mechanism that is generally irreversible with changing concentrations, but will allow $\mathrm{P}$ release when root exudates alter $\mathrm{pH}$, ensuring that $\mathrm{P}$ is available to growing crops (Church et al., 2016).

In Pennsylvania and many other historical coal-bearing areas, the treatment of drainage waters from coal mining to mitigate the effects of pyrite $\left(\mathrm{FeS}_{2}\right)$ oxidation has generated large quantities of mine drainage residual (MDR). MDR, being primarily iron oxyhydroxide, relies on adsorption as its dominant mechanism to bind $\mathrm{P}$, and its low cost makes it attractive as a potential amendment to reduce $\mathrm{P}$ mobility. In fact, while some uses for MDR as pigment and metal sorbents have been established, most of the solids are treated as wastes and disposed of by burial or injection into abandoned mines. Therefore, there is interest in finding other uses for MDR, including as a manure amendment to control $P$ runoff from Pennsylvania's animal agriculture industry.

MDR may also include minerals that contain aluminum, manganese, calcium and magnesium, all of which are known to complex phosphate and reduce its solubility in water (Adler and Sibrell, 2003; Sibrell et al., 2009; Li et al., 2011; Qin et al., 2018). Experiments have been conducted where agricultural soils are amended with MDR so that they will have increased $\mathrm{P}$ retention capabilities and be better able to retain DP introduced by agricultural activities (Penn et al., 2011), and MDR has been shown to be effective at removing DP from ditch waters draining fields (Penn et al., 2007). Likewise, MDRs have been shown to be equally effective as ferric sulfate in removing total $\mathrm{P}(\mathrm{TP})$ from dairy manure slurries in manure treatment systems by converting dissolved forms of $\mathrm{P}$ into particulate forms (Church et al., 2016, 2017), where it is then filtered in the final stage of the system.

We sought to test whether amending manure slurries with MDR is an effective means of reducing $P$ in runoff water from soils where the slurry was applied. Specific objectives were to: 1) identify MDRs with the highest potential to reduce $\mathrm{P}$ solubility in manure slurry, 2) identify an appropriate rate for dosing manure slurries with MDR, and finally, 3) to test the response of runoff water to treatment of dairy and swine manure slurries with MDR.

\section{MATERIALS AND METHODS}

\section{Mine Drainage Residual Dose Testing}

Initial dose testing was performed using a single dairy manure slurry on a number of MDRs for their capacity to decrease water extractable phosphorus (WEP). The MDRs shown (table 1), all from Pennsylvania coal mines. were chosen from an original 21 candidates by 1) excluding MDRs that exceeded the EPA Title 40- Part 503 Biosolids (EPA Title 40- Part 503, 2018) ceiling limits for any metal (Hedin, 2020), and 2) preferentially selecting MDRs potentially available for future field trials. To avoid potential effects from particle size mixing, each MDR was screened to $<1 \mathrm{~cm}$
Table 1. Water extractable phosphorus concentration remaining in dairy slurry after dosing and agitating manure with cumulative amounts of mine drainage residuals.

\begin{tabular}{lcccccc}
\hline & \multicolumn{6}{c}{ MDR Dosage $\left(\mathrm{g} \mathrm{L}^{-1}\right)$} \\
\cline { 2 - 7 } \multicolumn{1}{c}{ MDR Source } & 0 & 4 & 6 & 8 & 12 & 24 \\
\cline { 2 - 7 } Antrim & 4.5 & 4.0 & 4.0 & 3.9 & 3.6 & 3.1 \\
Blue Valley & 4.5 & 3.2 & 2.5 & 2.8 & 2.0 & 0.90 \\
Brandy Camp & 4.5 & 3.8 & 3.8 & 2.5 & 2.6 & 2.3 \\
Colver & 4.5 & 4.0 & 3.4 & 3.3 & 3.0 & 1.8 \\
Delmont & 4.5 & 3.7 & 3.7 & 2.6 & 2.3 & 2.0 \\
Hughes Borehole & 4.5 & 4.1 & 3.3 & 3.1 & 2.4 & 0.90 \\
Marchand & 4.5 & 3.3 & 3.0 & 2.8 & 2.2 & 1.7 \\
Mathies & 4.5 & 3.9 & 3.2 & 3.4 & 2.9 & 1.4 \\
Toby & 4.5 & 3.2 & 2.6 & 2.7 & 2.2 & 1.3 \\
\hline
\end{tabular}

particle size prior to the testing. While this eliminated large particles, the MDR samples still had variable particle size characteristics ranging from coarse sand to fine powder.

Manure slurry was collected in 5-gal (18.9-L) buckets from a dairy in Clarion County. The slurry density was determined by making multiple weight measurements of 200$\mathrm{mL}$ samples, subsequently the slurry was dosed with different concentrations of MDR. The MDR concentration $\left(\mathrm{g} \mathrm{L}^{-1}\right)$ for a particular test was determined from the measured weights of the MDR addition and manure slurry, and the previously calculated slurry density. Each test included a predetermined range (0-24 $\left.\mathrm{g} \mathrm{L}^{-1}\right)$ of MDR doses. The $\mathrm{MDR} /$ manure slurry mixtures $(500 \mathrm{~mL})$ were shaken vigorously by hand for $30 \mathrm{~s}$ then agitated on a laboratory shaker for $20 \mathrm{~m}$. An $80 \mathrm{~mL}$ subsample was collected and delivered to the Pennsylvania State University Agricultural Analytical Services Laboratory to be analyzed for water extractable P by the method of Kleinman et al., (2007). In this method 1$\mathrm{g}$ dry weight equivalent fresh manure slurry was shaken with $100 \mathrm{~mL}$ of distilled water on an end-over-end shaker for $60 \mathrm{~min}$, and samples of the mixture were sent to the laboratory. The mixture was then centrifuged $(2900 \mathrm{~g}$ for $20 \mathrm{~min}$ to facilitate filtration) and filtered through a Whatman \#1 filter paper. Filtrate $\mathrm{P}$ was determined by ICP-OES (table 1). The laboratory's hold time between sample receipt and extraction of $\mathrm{P}$ (for measurement on an ICP) was generally 3 to 5 days. These dose-effect times thus represent 3 to $5 \mathrm{~d}$ contact times between MDR and manure slurry.

Based on the results of MDR testing, we chose to use the Brandy Camp MDR for the subsequent rainfall simulations, and to perform the experiments using both dairy and swine manure slurries. The Brandy Camp MDR is an alkaline lime MDR produced at the Department of Environmental Protection's Brandy Camp treatment plant operated by the Pennsylvania Department of Environmental Protection and located in Luzerne County, Pennsylvania, where a large quantity of MDR is being produced and disposed of in strip mines (Beam, 2019) Prior to application, an additional dosing test with the Brandy Camp MDR was performed on each manure slurry, with the target goal of adding MDR in the amount necessary for WEP in manure slurry to reach its asymptote or, as in the case of swine manure slurry, to achieve $50 \%$ reduction in WEP (Callahan et al., 2002). For these tests, a 5-gal (18.9-L) bucket of manure slurry was collected from a dairy in Clarion County and a swine facility in 
Dauphin County, Pennsylvania, and the dosing test was performed as described above.

\section{RAINFALL EXPERIMENTS}

\section{Site Description and Manure Slurry Application}

A runoff study was established to determine the effects of MDR amendments on runoff $P$ losses using a protocol designed by the National Phosphorus Research Project (Sharpley et al., 2001). The runoff study was conducted on a Watson channery silt loam (fine-loamy, mixed, active, mesic Typic Fragiudult). The study site is located in North Umberland County, Pennsylvania within the Mahantango Creek watershed, which drains into the Chesapeake Bay via the Susquehanna River. The site slope gradient varied from $3 \%$ to $5 \%$. A mixed grass cover was removed by light tillage and hand weeding, and manure slurry was applied to a bare soil surface.

Sixteen $1-\times 2-\times 0.15-\mathrm{m}$ high steel frames (providing four replicates for all treatments arranged in random pair design) were driven $5 \mathrm{~cm}$ into the soil with a modified sledgehammer to border the top and sides of the plots. At the downslope end of the plot, steel gutters, pounded into the ground flush with the soil surface, funneled runoff into a collection bottle. Manure slurry was collected in 5-gal (18.9-L) buckets from a dairy in Clarion County and a swine facility in Dauphin County, Pennsylvania. To establish treatment conditions, manure slurry was applied at 45,300 and 73,600 $\mathrm{L} \mathrm{ha}^{-1}$ equivalent wet weight for liquid dairy and swine manure slurries, respectively. This was equivalent to a target rate of $26.5 \mathrm{~kg} \mathrm{ha}^{-1}$ TP for each manure slurry (table 2), the $\mathrm{P}$ rate needed to be taken up by a 61-bu ha-1 corn yield (Pennsylvania Act 38 Nutrient Management Program, 2019). Acid mine drain residuals were added to the slurries, vigorously handmixed with a paddle for $5 \mathrm{~min}$, and applied at 7 and $5 \mathrm{~g} \mathrm{~L}^{-1}$ for the dairy and swine manure slurries, respectively.

\section{Runoff Experiments}

Portable rainfall simulators (Humphry et al., 2002) were equipped with TeeJet 1/2 HH SS 50 WSQ nozzles (Spraying Systems Co., Wheaton, Ill.) placed approximately $3 \mathrm{~m}$ $(10 \mathrm{ft})$ above the soil surface. Nozzles supplied simulated rainfall at an intensity of $7.0 \mathrm{~cm} \mathrm{~h}^{-1}$ per the National Phosphorus Research Project (Sharpley et al., 2001), but modified in duration from $30 \mathrm{~min}$ to $20 \mathrm{~min}$, so as to represent a return period of 2 years. Water used to produce rain had less than $0.01 \mathrm{DP}$ and less than $0.1 \mathrm{TP}$, and was applied such that rain over the footprint of each plot was $85 \%$ uniform. Two simulators delivered rainfall, each one dedicated exclusively to a single manure slurry source to ensure within treatment uniformity, and simulators were calibrated to pressure and flow rate such that differences were slight.

On 4 October 2016, prior to manure slurry application, rainfall was administered to the bare plots to generate $20 \mathrm{~min}$

Table 2. Properties of manures used in study.

\begin{tabular}{|c|c|c|c|c|c|}
\hline \multirow[b]{2}{*}{ P Source } & \multirow{2}{*}{$\begin{array}{c}\text { Application } \\
\text { Rate } \\
\mathrm{Mg} \mathrm{Ha}^{-1} \text { (Wet) }\end{array}$} & $\begin{array}{c}\text { Dry } \\
\text { Matter }\end{array}$ & Total P & $\begin{array}{c}\text { Water } \\
\text { Extractable }^{[\mathrm{a}]}\end{array}$ & \multirow{2}{*}{$\begin{array}{c}\mathrm{WEP}^{[\mathrm{a}]} \text { : } \\
\mathrm{P}\end{array}$} \\
\hline & & \multicolumn{3}{|c|}{$\mathrm{g} \mathrm{kg}^{-1}$ (Dry Weight Basis) } & \\
\hline Dairy slurry & 45.3 & 40.0 & 6.60 & 2.1 & 3.1 \\
\hline Swine slurry & 73.6 & 25.0 & 20.7 & 4.3 & 4.81 \\
\hline
\end{tabular}

of runoff, with runoff volumes recorded every $5 \mathrm{~min}$. A 350$\mathrm{mL}$ sample taken at each 5-min interval was cooled to $4^{\circ} \mathrm{C}$ $\left(39^{\circ} \mathrm{F}\right)$. The remaining portion of runoff was composited in a large barrel, stirred, and a final $350-\mathrm{mL}$ composite sample was collected. Seventeen days later on 21 October, after soil moisture reached and stabilized at field capacity, treated and untreated dairy and swine manure slurries were applied to the bare soil surface. One day after manure slurry was applied (22 Oct.) a second rainfall simulation occurred following the protocol described above. Subsequent rain simulations occurred on 25 October (three days after manure slurry application) and on 2 and 10 November 2016 (12 and 20 days after manure slurry application, respectively). Runoff samples taken throughout the 20-min runoff period were promptly filtered through $0.45-\mu \mathrm{m}\left(0.17 \times 10^{-6} \mathrm{in}\right.$.) polyethersulfone membrane filters (Pall Laboratory, Port Washington, N.Y.). Filtered and unfiltered samples were stored at $4^{\circ} \mathrm{C}\left(39^{\circ} \mathrm{F}\right)$ prior to laboratory analysis. Following manure slurry application, and between rainfall events, plots were covered in the event of likely rainfall, but otherwise were left uncovered to allow for typical soil drying.

\section{LABORATORY ANALYSIS \\ Soil}

Samples of the Watson soil were obtained from directly adjacent to each plot prior to manure slurry application. One sample [0 to $2.5 \mathrm{~cm}$ depth (0 to $1 \mathrm{in}$.)] was collected near each plot (10 total) using a stainless steel probe $[2.5 \mathrm{~cm}$ (1 in.) diameter] and combined to form a single composite sample. Samples were air dried and sieved [2 mm (0.08 in.)] prior to analysis. Soils were analyzed for Mehlich-3 P (Mehlich, 1984) with P determined by inductively coupled optical emission spectrophotometer (ICP-OES, Varian) and for WEP.

Soil was analyzed for Mehlich-3 P by shaking $2.5 \mathrm{~g}$ of soil in $25 \mathrm{~mL}$ of Mehlich-3 solution $\left(0.2 \mathrm{M} \mathrm{CH}_{3} \mathrm{COOH}+\right.$ $0.25 \mathrm{M} \mathrm{NH}_{4} \mathrm{NO}_{3}+0.015 \mathrm{M} \mathrm{NH}_{4} \mathrm{~F}+0.013 \mathrm{M} \mathrm{HNO}_{3}+0.001$ M EDTA) for $5 \mathrm{~min}$. The supernatant was filtered $(0.45 \mu \mathrm{m}$, polyethersulfone membrane filter), and $\mathrm{P}$ in the neutralized filtrate was determined by ICP-OES. Water-extractable soil $\mathrm{P}$ was measured by shaking $2 \mathrm{~g}$ of soil in $20 \mathrm{~mL}$ of distilled water for $1 \mathrm{~h}$, filtering the supernatant through a Whatman \#1 paper filter and determining element concentrations by ICP-OES (Varian). Soil $\mathrm{pH}$ was determined by mixing air dry soil with distilled water $(5 \mathrm{~g}: 5 \mathrm{~mL})$.

\section{Manure}

Manure slurries were extracted with aqua regia and hydrogen peroxide following a modified EPA Standard Method 3050B (Kimbrough and Wakakuwa, 1989). Solids were oven dried at $110^{\circ} \mathrm{C}$ for $16 \mathrm{~h}$ to determine solids content, but were digested wet, such that the sample size contained $0.5 \mathrm{~g}$ of solid material. Following dilution to final volumes and filtration (Whatman No. 1), P analysis was then performed on all extracts by ICP-OES. Water extraction was conducted to assess readily soluble phases of $\mathrm{P}$ by the method of Kleinman et al. (2007). One g dry weight equivalent fresh manure slurry was shaken with $100 \mathrm{~mL}$ of distilled water on an end-over-end shaker for $60 \mathrm{~min}$. The mixture was then centrifuged ( $2900 \mathrm{~g}$ for $20 \mathrm{~min}$ to facilitate 
filtration) and filtered through a Whatman \#1 filter paper. Filtrate $\mathrm{P}$ was determined by ICP-OES. Dry matter content of all manure slurries was determined gravimetrically after oven-drying the manure slurries at $70^{\circ} \mathrm{C}$ for $48 \mathrm{~h}$.

\section{Water}

Dissolved $\mathrm{P}$ was determined on runoff samples filtered through $0.45 \mu \mathrm{m}\left(0.17 \times 10^{-6} \mathrm{in}\right.$. $)$ polyethersulfone membrane filters (Pall Laboratory, Port Washington, N.Y.). Total $\mathrm{P}$ was measured on unfiltered runoff samples by digestion with aqua regia $\left(25 \% 12 \mathrm{M} \mathrm{HNO}_{3}+75 \% 12 \mathrm{M} \mathrm{HCl}\right)$ added to the sample and analyzed by ICP-OES. Runoff samples were analyzed for total solids by evaporating $200 \mathrm{~mL}(7 \mathrm{oz})$ of unfiltered water in the oven at $70^{\circ} \mathrm{C}\left(158^{\circ} \mathrm{F}\right)$ and weighing the remaining material.

\section{Statistical ANALYSIS}

Comparisons of the two-treatment design were made using a two-sample t-Test procedure in SAS (SAS Institute, 2012). Differences in treatment means were determined to be significant if $p$ values were less than 0.05 and 0.10 , as noted in the figures and tables. Where variances were not equal Satterwaite's results were used to determine significance; otherwise, significance for pooled $p$ values were reported.

\section{RESULTS AND DISCUSSION Dose Testing}

The initial dose testing explored the variable ability of MDR samples to decrease WEP concentrations in dairy manure slurry (table 1). The raw manure slurry contained $4,546 \mathrm{mg} / \mathrm{kg}$ WEP and had a phosphorus source coeficient of 0.53 (average of three samples). All MDR treatments exhibited a dose-response relationship where increased additions of MDR resulted in lower WEP, lowering WEP by $27 \%$ to $44 \%$ at the $8 \mathrm{~g} \mathrm{~L}^{-1}$ dose. There was not a strong correlation between the type of MDR and WEP removal at $8 \mathrm{~g} \mathrm{~L}^{-1}$. The three best performers were lime MDRs (Brandy Camp, Delmont, and Toby) and the next two best performers were iron oxide MDRs (Marchand and Blue Valley). At the highest loading, $24 \mathrm{~g} \mathrm{~L}^{-1}$, the best removal was from two iron oxide MDRs (Hughes and Blue Valley). The Brandy Camp and Delmont MDRs (both lime MDRs) which had the highest WEP removal at $8 \mathrm{~g} \mathrm{~L}^{-1}$ had the lowest at $24 \mathrm{~g} \mathrm{~L}^{-1}$. Therefore, because the Brandy Camp MDR was found to contain low levels of elements identified in the EPA Part 503 Biosolids (EPA Title 40- Part 503, 2018) ceiling limits (Hedin, 2020), and because initial dose testing indicated it was effective at reducing WEP (table 1), it was chosen for use in the rainfall experiment with the goal of using a concentration of MDR amendment that would result in a $50 \%$ reduction in WEP (Callahan et al., 2002). Also, because decreasing average particle size was shown to have a greater effect on WEP reduction experiments (Hedin, 2020), the MDR used in the rainfall experiments was milled using a Pulva Model B mill to a fine powder (median diameter $25 \mu \mathrm{m}$ with greater than $96 \%$ smaller than $180 \mu \mathrm{m})$. This milling increased the proportion of $<180 \mu \mathrm{m}$ material from $37 \%$ to $96 \%$.
Prior to manure slurry application to the plots, another dosing test was performed with the Brandy Camp MDR on the dairy and swine manure slurries to be used in the rainfall experiments. As can be seen in figure 1, for both the dairy and swine manure slurries, there was a decrease in WEP upon amending with MDR, a result also observed in an earlier study with this same MDR (Sibrell et al., 2015). It is also clear that amending the swine manure slurry with MDR was more effective at reducing WEP than with dairy manure slurry, possibly due to dissolved P speciation differences between manure slurries of the different species. In fact, in our testing, the MDR amended dairy manure slurry never achieved the goal of 50\% WEP reduction (fig. 1a), whereas with swine manure slurry (fig. 1b), we ultimately achieved a $75 \%$ reduction in WEP at the highest concentration of MDR amendment tested.

\section{DAIRY RUNOFF}

Amending dairy manure slurry with MDR was effective at reducing concentrations of DP during Event 1, with concentrations of DP for all but the final time interval being significant (fig. 2a). There were no significant differences in particulate $\mathrm{P}(\mathrm{PP})$ concentrations. Likewise, there was a significant decrease in flow-weighted DP concentrations overall for Event 1 (table 3a). There was no significant difference in PP or TP losses in runoff for any of the events. This observation is consistent with previous results (Sibrell et al., 2015) showing that DP is converted to particulate form upon addition of MDR, and similar patterns under simulated rainfall conditions were also reported by Buda et al. (2010), where manure slurry was treated with rare earth elements and subjected to runoff experiments. As with Buda et al. (2010), examination of the actual runoff particles to discern whether they were composed of $\mathrm{P}$ sorbed to MDR particles was beyond the scope of this study.

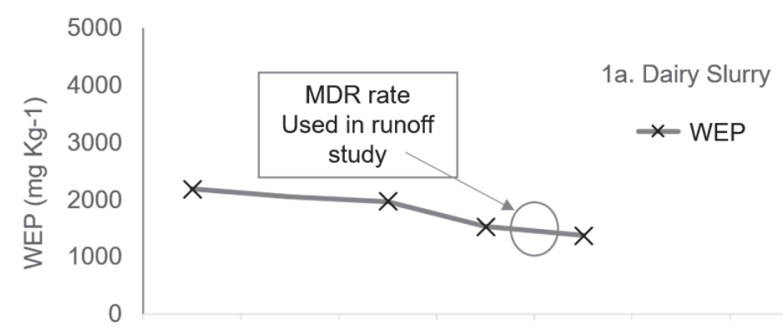

(a) Dairy slurry dose test

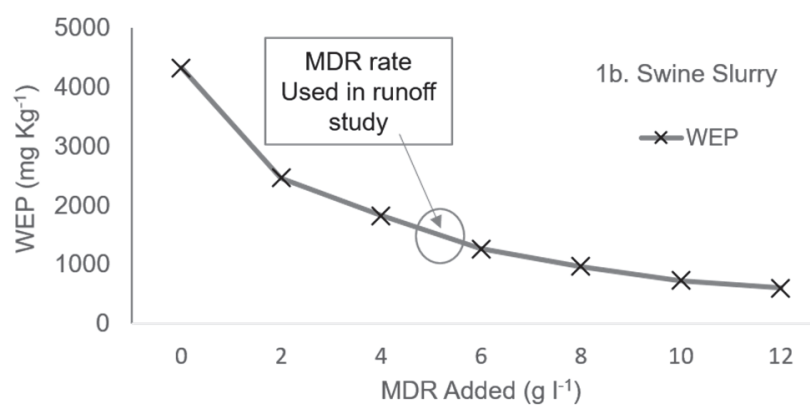

(b) Swine slurry dose test

Figure 1. Water extractable phosphorus concentration after dosing manure with cumulative amounts of acid mine drainage residuals. 


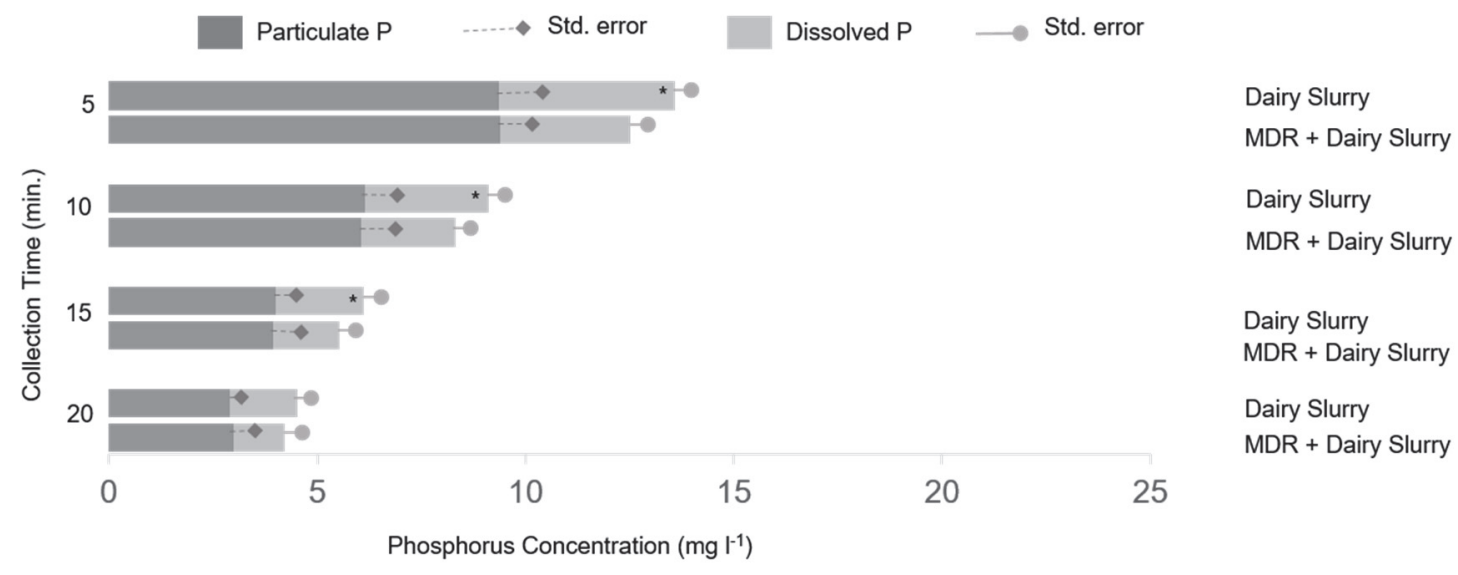

Figure 2a. Flow weighted phosphorus concentration $\left(\mathrm{mg} \mathrm{L}^{-1}\right)$ in runoff from soils amended with raw dairy slurry and dairy slurry treated with mine drainage residuals collected at 5-, 10-, 15-, and 20-min intervals during first event after manure application.

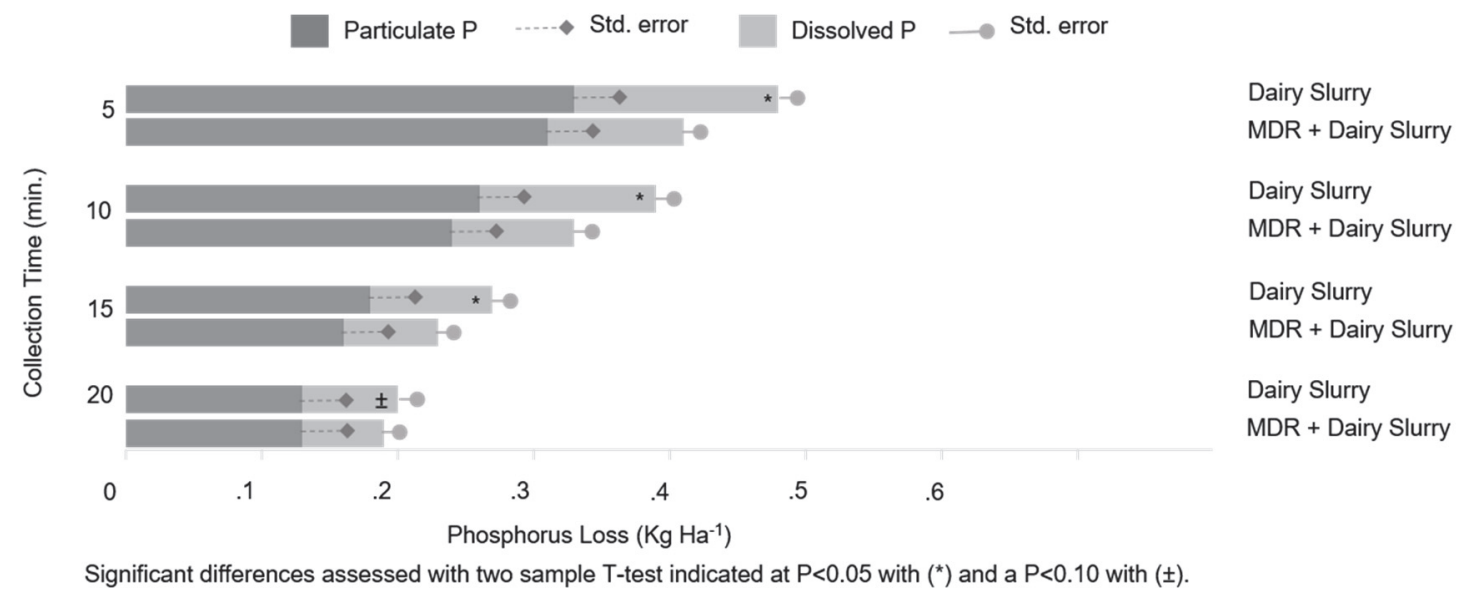

Figure 2b. Phosphorus loss $\left(\mathrm{kg} \mathrm{ha}^{-1}\right)$ in runoff from soils amended with raw dairy slurry and dairy slurry treated with mine drainage residuals collected at 5-, 10-, 15-, and 20-min intervals during first event after manure application.

Table 3a. Flow weighted phosphorus concentration $\left(\mathrm{mg} \mathrm{L}^{-1}\right)$ in runoff from bare soil (background) and dairy slurry amended soils after 20 min of runoff over four sampling dates.

\begin{tabular}{|c|c|c|c|c|c|c|}
\hline & & Bare & & & & \\
\hline & D Form & Soil & Event 1 & Event 2 & Event 3 & Event 4 \\
\hline Treatment & PForm & & & mg L & & \\
\hline $\begin{array}{c}\text { Dairy Slurry } \\
\text { MDR }+ \text { Dairy Slurry }\end{array}$ & DP & $<0.01$ & $\begin{array}{c}3.32 \\
1.98 *\end{array}$ & $\begin{array}{l}0.50 \\
0.39\end{array}$ & 0.18 & $\begin{array}{l}0.10 \\
0.06\end{array}$ \\
\hline Dairy Slurry & PP & 0.87 & 4.54 & 1.1 & 0.81 & 0.34 \\
\hline MDR + Dairy Slurry & & 0.83 & 5.32 & 1.18 & 0.84 & 0.31 \\
\hline Dairy Slurry & $\mathrm{TP}$ & 0.87 & 7.86 & 1.60 & 1.0 & 0.44 \\
\hline MDR + Dairy Slurry & & 0.83 & 7.30 & 1.57 & 0.97 & 0.37 \\
\hline
\end{tabular}

[a] Significant differences assessed with two sample T-test indicated at $\mathrm{P}<0.05$ with (*) and a $\mathrm{P}<0.10$ with $( \pm)$.

Table 3b. Phosphorus loads in runoff $\left(\mathrm{kg} \mathrm{ha}^{-1}\right)$ in runoff from bare soil (background) and dairy slurry amended soils after 20 min of runoff over four sampling dates.

\begin{tabular}{ccccccc}
\hline & & \multicolumn{2}{c}{$\begin{array}{c}\text { Bare } \\
\text { Soil }\end{array}$} & \multicolumn{5}{c}{ Event 1 } & Event 2 Event 3 & Event 4 \\
\cline { 3 - 7 } Treatment & P Form & \multicolumn{5}{c|}{$\mathrm{kg} \mathrm{ha}^{-1[\mathrm{a}]}$} \\
\cline { 3 - 7 } Dairy Slurry & DP & 0.00 & 0.46 & 0.10 & 0.03 & 0.02 \\
MDR + Dairy Slurry & & 0.00 & $0.32^{*}$ & $0.07^{ \pm}$ & 0.03 & 0.01 \\
\hline Dairy Slurry & PP & 0.13 & 0.89 & 0.24 & 0.16 & 0.07 \\
MDR + Dairy Slurry & & 0.12 & 0.84 & 0.23 & 0.15 & 0.07 \\
\hline Dairy Slurry & TP & 0.13 & 1.35 & 0.34 & 0.19 & 0.09 \\
MDR + Dairy Slurry & & 0.12 & 1.16 & 0.30 & 0.18 & 0.08 \\
\hline
\end{tabular}

[a] Significant differences assessed with two sample T-test indicated at $\mathrm{P}<0.05$ with $(*)$ and a $\mathrm{P}<0.10$ with $( \pm)$.
Trends in concentrations and loads of $\mathrm{P}$ were consistent within the individual runoff events (fig. 2b). Both concentrations and loads of particulate and TP declined over each sampling interval from the onset of runoff generation to the conclusion of the event. Differences between the two manure slurry treatments were only observed for TP in samples obtained from earlier in the runoff events $(0-5,5-10$, and $10-$ $15 \mathrm{~min}$ ). Differences were not apparent in particulate $\mathrm{P}$ nor were they observed in TP in samples obtained towards the end of an event.

\section{SWINE RUNOFF}

In contrast with dairy manure slurry results, runoff from swine manure slurry amended plots showed no significant differences in concentration for DP, PP, or TP for any of the intervals in Event 1 (fig. 3a). Likewise, there were also no significant differences in flow-weighted DP, PP, or TP concentrations for any of the four events (table 4a). Notably, variances were greater from the swine manure slurry treatments, particularly for losses (fig. 3b). While concentrations did decline during the events, as they did with dairy manure slurry treatments and as has been reported elsewhere (e.g., Kleinman et al., 2006), no such trends were manifest for losses. 


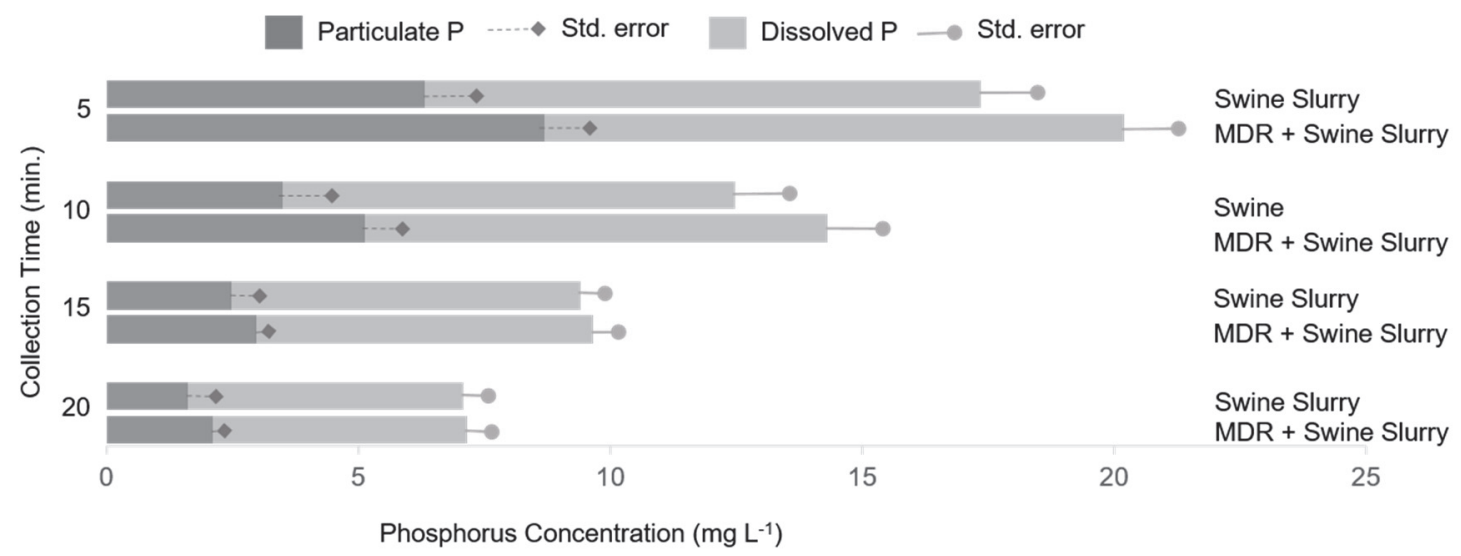

Figure 3a. Flow weighted phosphorus concentration $\left(\mathrm{mg} \mathrm{L}^{-1}\right)$ in runoff from bare soil (background) and dairy slurry amended soils after 20 min of runoff over four sampling dates.

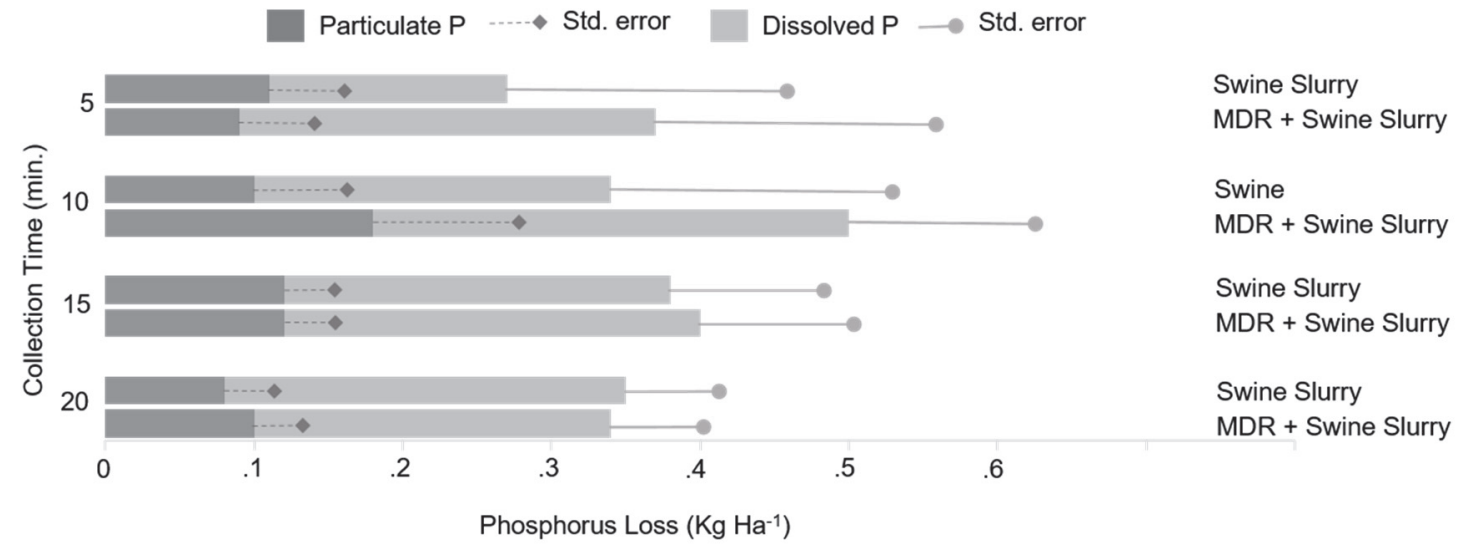

Significant differences assessed with two sample T-test indicated at $P<0.05$ with $\left({ }^{*}\right)$ and a $P<0.10$ with $( \pm)$.

Figure 3b. Phosphorus loss $\left(\mathrm{kg} \mathrm{ha}^{-1}\right)$ in runoff from soils amended with raw swine slurry and swine slurry treated with mine drainage residuals collected at 5-, 10-, 15-, and 20-min intervals during first event after manure application.

Table 4a. Flow weighted phosphorus concentration $\left(\mathrm{mg} \mathrm{L}^{-1}\right)$ in runoff from bare soil (background) and swine slurry amended soils after 20 min of runoff over four sampling dates.

\begin{tabular}{|c|c|c|c|c|c|c|}
\hline \multirow[b]{3}{*}{ Treatment } & \multirow[b]{3}{*}{ P Form } & \multicolumn{5}{|c|}{$\mathrm{Mg} \mathrm{L}^{-1}$} \\
\hline & & Bare & & & & \\
\hline & & Soil & Event 1 & Event 2 & Event 3 & Event 4 \\
\hline Swine Slurry & DP & 0.04 & 7.18 & 1.33 & 0.57 & 0.39 \\
\hline MDR + Swine Slurry & & 0.04 & 7.45 & 1.19 & 0.44 & 0.32 \\
\hline Swine Slurry & PP & 0.84 & 2.79 & 1.00 & 0.98 & 0.54 \\
\hline MDR + Swine Slurry & & 0.95 & 4.19 & 1.28 & 1.26 & 0.79 \\
\hline Swine Slurry & TP & 0.89 & 9.97 & 2.33 & 1.55 & 1.92 \\
\hline MDR + Swine Slurry & & 0.98 & 11.6 & 2.47 & 1.71 & 1.11 \\
\hline
\end{tabular}

Table 4b. Phosphorus loads in runoff $\left(\mathrm{kg} \mathrm{ha}^{-1}\right)$ in runoff from bare soil (background) and swine slurry amended soils after 20 min of runoff over four sampling dates.

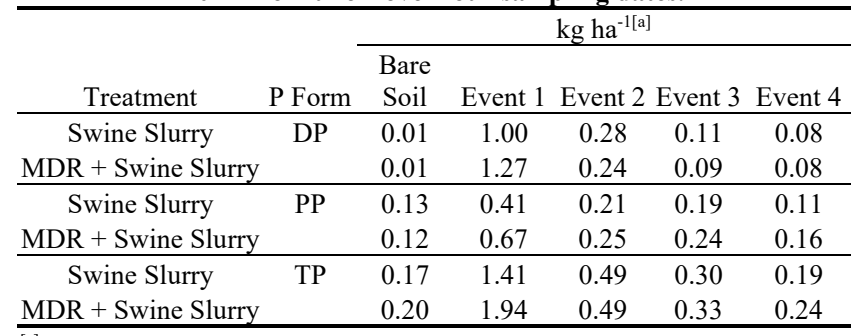

[a] Significant differences assessed with two sample T-test indicated at $\mathrm{P}<0.05$ with (*) and a $\mathrm{P}<0.10$ with $( \pm$ ).
For the swine plots, P loads in runoff showed no significant differences (fig. 3b). Likewise, there were no significant differences in $\mathrm{P}$ loads in runoff found for any of the events overall (table 4b). A possible explanation for these results relates to observations made during the experiment. The greater solids content in dairy manure slurry resulted in a layer of organic material covering the soil surface. Most of the MDR containing sorbed $\mathrm{P}$ was embedded within this organic mat and was protected against wash off or repeated contact with runoff that may desorb P. In contrast, the swine manure slurry contained a much lower solids content, and a lot of bare soil was exposed after swine slurry application. Dissolved $\mathrm{P}$ in the liquid portion of the untreated swine slurry was subject to infiltration into the soil during application and during the first minutes of rainfall prior to runoff. For MDR treated swine slurry, MDR particulates could be entrained on this exposed surface and be subject to wash off or P desorption due to contact with runoff.

\section{CONCLUSION}

As expected, amending dairy manure slurry with MDR resulted in reduced flow weighted DP concentrations and P loads in runoff during the first three time intervals of event 1 
and significantly reduced overall flow weighted DP concentration in events 1 and 2. Surprisingly, while dosing tests showed greater reductions in DP in dosing tests in the laboratory, amending swine manure slurries with MDR did not result in any significant differences in $\mathrm{P}$ concentrations of loads in runoff. The results of this study suggest that amending dairy manure slurries having relatively high solids content with MDR will reduce DP losses in runoff. While our explanation for why amending slurries with MDR did not work for swine manure slurry is speculative, it is clear that an observed reduction in WEP in laboratory tests does not necessarily predict that $\mathrm{P}$ loss during runoff will be reduced. This study underscores the importance of testing under simulated field conditions before making manure management recommendations based on WEP response to MDR addition under laboratory conditions.

\section{IMPLICATIONS}

Providing that experiments indicate $P$ runoff from a dairy manure slurries with high WEP can be reduced by amending it with MDR, the costs associated can be economical, though the costs will be largely affected by the type of MDR used, as well as the WEP concentration of the dairy manure slurry to be treated (manure slurries with high WEP concentrations show greater reduction upon amendment than do manure slurries with low WEP). For example, for a high-WEP dairy manure slurry with a $5 \mathrm{~g} \mathrm{~L}^{-1} \mathrm{MDR}$ amendment, and a MDR cost of $\$ 272 \mathrm{t}^{-1}$, the estimated treatment cost is $\$ 791$ per 100,000 gal of manure slurry including the cost to purchase processed MDR (60\% solids, screened, bulk), truck it 100 miles, apply it to a large manure slurry storage tank, and mix for 3-4 h with a pump. Assuming that manure slurry is produced by cows at a rate of 16 gal day $^{-1}$, then the annualized unit cost per cow is $\$ 45$ cow $^{-1}$ year $^{-1}$. If the treatment decreases WEP by 2,000 $\mathrm{mg} \mathrm{kg}^{-1}$, then the unit cost of P removal is $\$ 17.10 \mathrm{~kg}^{-1} \mathrm{P}$. Amending dairy manure slurries with MDR then, appears to be a viable option to reduce runoff from agricultural fields, providing that appropriate tests to ensure its effectiveness are performed.

\section{ACKNOWLEDGEMENTS}

Special thanks are extended to Sarah Fishel and Joan Weaver (Pasture Systems and Water Management Research Laboratory, USDA, University Park, Pa.), and David Otto (retired), Michael Reiner, Tanner Wolfgang, Terry Troutman, and Todd Strohecker (Pasture Systems and Water Management Research Laboratory, USDA, Klingerstown, $\mathrm{Pa}$.), who contributed significantly research presented here.

Funding for this study was provided by a Growing Greener Grant from the Pennsylvania Department of Environmental Protection- Grant Number 4100059663.

\section{REFERENCES}

Adler, P. R., \& Sibrell, P. L. (2003). Sequestration of phosphorus by acid mine drainage floc. JEQ, 32(3), 1122-1129. https://doi.org/10.2134/jeq2003.1122

Allred, B. J. (2017). Batch test screening of industrial product/byproduct filter materials for agricultural drainage water treatment. Water, 9(10), 791. https://doi.org/10.3390/w9100791
Beam, R. (2019). Overview of active mine drainage treatment facilities currently operated by the Bureau of Abandoned Mine Reclamations. Proc. 40th Annual West Virginia Mine Drainage Task Force Symp. Retrieved from

https://wvmdtaskforce.files.wordpress.com/2019/03/2019-1600beam-bamr-active-treatment-systems-2019-

wv_task_force_final-version.pdf

Brennan, R. B., Fenton, O., Grant, J., \& Healy, M. G. (2011). Impact of chemical amendment of dairy cattle slurry on phosphorus, suspended sediment and metal loss to runoff from a grassland soil. Sci. Total Environ., 409(23), 5111-5118. https://doi.org/10.1016/j.scitotenv.2011.08.016

Brennan, R. B., Wall, D. P., Fenton, O., Grant, J., Sharpley, A. N., \& Healy, M. G. (2014). Impact of chemical amendment of dairy cattle slurry on soil phosphorus dynamics following application to five soils. Commun. Soil Sci. Plant Analysis, 45(16), 22152233. https://doi.org/10.1080/00103624.2014.912293

Buda, A. R., Church, C., Kleinman, P. J., Saporito, L. S., Moyer, B. G., \& Tao, L. (2010). Using rare earth elements to control phosphorus and track manure in runoff. $J E Q, 39(3), 1028-1035$. https://doi.org/10.2134/jeq2009.0359

Callahan, M. P., Kleinman, P. J., Sharpley, A. N., \& Stout, W. L. (2002). Assessing the efficacy of alternative phosphorus sorbing soil amendments. Soil Sci., 167(8), 539-547. https://doi.org/10.1097/00010694-200208000-00005

Chardon, W. J., Groenenberg, J. E., Temminghoff, E. J., \& Koopmans, G. F. (2012). Use of reactive materials to bind phosphorus. JEQ, 41(3), 636-646. https://doi.org/10.2134/jeq2011.0055

Church, C. D., Hristov, A. N., Bryant, R. B., Fishel, S. K., \& Kleinman, P. J. (2016). A novel treatment system to remove phosphorus from liquid manure. Appl. Eng. Agric., 32(1), 103112. https://doi.org/10.13031/aea.32.10999

Church, C. D., Hristov, A., Bryant, R. B., \& Kleinman, P. J. (2017). Processes and treatment systems for treating high phosphorus containing fluids. U.S. Patent 9,790.110B2.

Dou, Z., Zhang, G. Y., Stout, W. L., Toth, J. D., \& Ferguson, J. D. (2003). Efficacy of alum and coal combustion by-products in stabilizing manure phosphorus. JEQ, 32(4), 1490-1497. https://doi.org/10.2134/jeq2003.1490

EPA Title 40-Part 503. (2018). Standards for the use or disposal of sewage sludge. Code of Federal Regulations. Washington, DC: EPA. Retrieved from https://www.govinfo.gov/content/pkg/CFR-2018-title40vol32/xml/CFR-2018-title40-vol32-part503.xml

Hedin, R. (2020). Characteristics of solids produced from coal mine drainage and their suitability for phosphorus control in dairy manure management. JEQ, 49(6), 1502-1514. https://doi.org/10.1002/jeq2.20157

Humphry, J. B., Daniel, T. C., Edwards, D. R., \& Sharpley, A. N. (2002). A portable rainfall simulator for plot-scale runoff studies. Appl. Eng. Agric., 18(2), 199-204. https://doi.org/10.13031/2013.7789

Kalbasi, M., \& Karthikeyan, K. G. (2004). Phosphorus dynamics in soils receiving chemically treated dairy manure. JEQ, 33(6), 2296-2305. https://doi.org/10.2134/jeq2004.2296

Kennedy, C. D., Kleinman, P. J., DeMoranville, C. J., Elkin, K. R., Bryant, R. B., \& Buda, A. R. (2017). Managing surface water inputs to reduce phosphorus loss from cranberry farms. $J E Q$, 46(6), 1472-1479. https://doi.org/10.2134/jeq2017.04.0134

Kimbrough, D. E., \& Wakakuwa, J. R. (1989). Acid digestion for sediments, sludges, soils, and solid wastes. A proposed alternative to EPA SW 846 Method 3050. Environ. Sci. Technol., 23(7), 898-900. https://doi.org/10.1021/es00065a021 
King, K. W., Williams, M. R., LaBarge, G. A., Smith, D. R., Reutter, J. M., Duncan, E. W., \& Pease, L. A. (2018). Addressing agricultural phosphorus loss in artificially drained landscapes with 4R nutrient management practices. JSWC, 73(1), 35-47. https://doi.org/10.2489/jswc.73.1.35

Kleinman, P. J. A., Sharpley, A. N., Veith, T. L., Maguire, R. O., \& Vadas, P. A. (2004). Evaluation of phosphorus transport in surface runoff from packed soil boxes. JEQ, 33(4), 1413-1423. https://doi.org/10.2134/jeq2004.1413

Kleinman, P. J. A., Sharpley, A. N., Wolf, A. M., Beegle, D. B., \& Moore Jr., P. A. (2002). Measuring water-extractable phosphorus in manure as an indicator of phosphorus in runoff. SSSAJ, 66(6), 2009-2015. https://doi.org/10.2136/sssaj2002.2009

Kleinman, P. J. A., Srinivasan, M. S., Dell, C. J., Schmidt, J. P., Sharpley, A. N., \& Bryant, R. B. (2006). Role of rainfall intensity and hydrology in nutrient transport via surface runoff. JEQ, 35(4), 1248-1259. https://doi.org/10.2134/jeq2006.0015

Kleinman, P. J. A., Sullivan, D., Wolf, A., Brandt, R., Dou, Z., Elliott, H.,... Zhang, T. (2007). Selection of a water-extractable phosphorus test for manures and biosolids as an indicator of runoff loss potential. JEQ, 36(5), 1357-1367. https://doi.org/10.2134/jeq2006.0450

Li, R., Lin, Z., Tao, T., \& Bo, L. (2011). Phosphorus removal performance of acid mine drainage from wastewater. $J$. Hazardous Materials, 190(1), 669-676. https://doi.org/10.1016/j.jhazmat.2011.03.097

Maguire, R. O., Kleinman, P. J., Dell, C. J., Beegle, D. B., Brandt, R. C., McGrath, J. M., \& Ketterings, Q. M. (2011). Manure application technology in reduced tillage and forage systems: A review. JEQ, 40(2), 292-301. https://doi.org/10.2134/jeq2009.0228

Mehlich, A. (1984). Mehlich 3 soil test extractant: A modification of Mehlich 2 extractant. Commun. Soil Sci. Plant Analysis, 15(12), 1409-1416. https://doi.org/10.1080/00103628409367568

Miller, M. L., Bhadha, J. H., O'Connor, G. A., Jawitz, J. W., \& Mitchell, J. (2011). Aluminum water treatment residuals as permeable reactive barrier sorbents to reduce phosphorus losses. Chemosphere, 83(7), 978-983. https://doi.org/10.1016/j.chemosphere.2011.02.014

Moore Jr., P. A., \& Miller, D. M. (1994). Reducing phosphorus solubility in poultry litter with aluminum, calcium, and iron amendments. JEQ, 23(2), 325-330. https://doi.org/10.2134/jeq1994.00472425002300020016x
Moore Jr., P. A., Daniel, T. C., \& Edwards, D. R. (2000).

Decreasing phosphorus runoff and inhibiting ammonia loss from poultry manure with aluminum sulfate. $J E Q, 29(1), 37-49$. https://doi.org/10.2134/jeq2000.00472425002900010006x

Penn, C. J., Bryant, R. B., Callahan, M. P., \& McGrath, J. M. (2011). Use of industrial by-products to sorb and retain phosphorus. Commun. Soil Sci. Plant Analysis, 42(6), 633-644. https://doi.org/10.1080/00103624.2011.550374

Penn, C. J., Bryant, R. B., Kleinman, P. J., \& Allen, A. L. (2007). Removing dissolved phosphorus from drainage ditch water with phosphorus sorbing materials. JSWC, 62(4), 269-276.

Pennsylvania Act 38 Nutrient Management Program. (2019). Technical manual. Retrieved from https://extension.psu.edu/programs/nutrientmanagement/planning-resources/alternative-tech-manual

Qin, Z., Shober, A. L., Scheckel, K. G., Penn, C. J., \& Turner, K. C. (2018). Mechanisms of phosphorus removal by phosphorus sorbing materials. JEQ, 47(5), 1232-1241. https://doi.org/10.2134/jeq2018.02.0064

SAS Institute. (2012). The SAS system. Ver. 9.2. Cary, NC: SAS Institute.

Sharpley, A. N., McDowell, R. W., Weld, J. L., \& Kleinman, P. J. A. (2001). Assessing site vulnerability to phosphorus loss in an agricultural watershed. JEQ, 30(6), 2026-2036. https://doi.org/10.2134/jeq2001.2026

Sharpley, A., \& Moyer, B. (2000). Phosphorus forms in manure and compost and their release during simulated rainfall. JEQ, 29(5), 1462-1469. https://doi.org/10.2134/jeq2000.00472425002900050012x

Sibrell, P. L., Montgomery, G. A., Ritenour, K. L., \& Tucker, T. W. (2009). Removal of phosphorus from agricultural wastewaters using adsorption media prepared from acid mine drainage sludge. Water Res., 43(8), 2240-2250. https://doi.org/10.1016/j.watres.2009.02.010

Sibrell, P. L., Penn, C. J., \& Hedin, R. S. (2015). Reducing soluble phosphorus in dairy effluents through application of mine drainage residuals. Commun. Soil Sci. Plant Analysis, 46(5), 545-563. https://doi.org/10.1080/00103624.2014.998339

Smith, D. R., Moore Jr., P. A., Griffis, C. L., Daniel, T. C., Edwards, D. R., \& Boothe, D. L. (2001). Effects of alum and aluminum chloride on phosphorus runoff from swine manure. $J E Q, 30(3), 992-998$. https://doi.org/10.2134/jeq2001.303992x

Wilson, J. D., Zheljazkov, V. D., Rathgeber, B., Caldwell, C. D., \& Burton, D. L. (2008). Reduction in phosphorus availability in poultry and diary manure by mineral amendments. Soil Sci. Plant Nutrition, 54(4), 600-605. https://doi.org/10.1111/j.17470765.2008.00274.x 